\title{
Benchmarking Modelling in the Context of Banking Sector Deepening and Long-Term Economic Growth
}

\author{
Ali Al-Moulani* and Constantinos Alexiou** \\ *Bahrain Economists Society, Manama, Kingdom of Bahrain \\ ** Corresponding author: Cranfield University, School of Management \\ College road, MK43 0AL, UK
}

\begin{abstract}
This paper identifies a host of key factors that influence the development of the banking sector as well as enhances our understanding of benchmarking modelling as a means of stimulating economic growth. A novel benchmarking method is utilized that assesses the level of banking sector depth in a country against its counterparts in the top quartile countries using mixed effects and system GMM for dynamic panel data models. The results suggest that the development of the banking sector is contingent upon factors that can be traced within the structure of the sector, the macroeconomic environment as well as the governing, institutional, and legal frameworks. The paper presents four benchmarking models that potentially provide policymakers with tools to benchmark the levels of banking sector development against their peers in countries in which the particular sector contributes significantly to economic growth.
\end{abstract}

Key words: Banking sector depth, Benchmarking, Economic Growth JEL Classification codes: G2; O16

\section{Introduction}

The finance-growth nexus literature contends that the development of the financial sector can stimulate economic growth by overcoming market frictions. High transaction costs, lack of contract enforcement, and information asymmetry are market issues that lead to the misallocation of resources, which in turn deters long-term economic growth. The financial sector development deals with such imperfections by producing ex ante information for potential investments, monitoring investments and exerting corporate governance after providing finance, diversifying and managing risk, pooling and mobilising savings, and easing the exchange of goods and services (Levine, 2005). Beck and Levine (2003) contend that legal institutions explain the differences in the levels of financial development across countries in two ways. Firstly, financial intermediaries and markets grow in countries in which the legal systems enforce private property rights, support private contractual agreements, and protect the investors' legal rights. Secondly, the differences in investors' protection, the contracting environment, and financial development are due to the number of legal traditions that emerged in Europe and were spread internationally through conquest, colonisation, and imitation. La Porta et al. $(1997,1998)$ show that countries with poorer investor protections have smaller and narrower equity and debt markets. La Porta et al. (1997) illustrate that countries adopting the French civil law have weaker investor protections and less developed capital markets in comparison to countries following the common law. Furthermore, using data for 72 countries for the period between 1978 and 2000, Demetriades and Andrianova(2005) find that the rule of law is a positive and statistically significant determinant of banking sector development. Similar results are also provided by Ben Naceur et al., (2014), Donia, (2012), and Gazdar \& Cherif, (2014).

Despite the abundance of empirical evidence supporting the instrumental role that the financial sector plays in stimulating growth, the intensity of the after-effects of the Global Financial Crisis that erupted in 2008 on the global economic growth prompted many scholars to revisit and reassess the relationship between financial development and economic growth. More specifically, it is suggested that countries with highly developed banking sectors where the extended credit to the private sector exceeds the size of their GDP - such as Iceland, Ireland, Spain, Portugal, the United Kingdom, and the United States - faced considerable difficulties during the crisis.

The current findings in the literature suggest that the relationship between banking sector development and long-term economic growth is non-linear where the positive relationship between the two variables turns negative beyond a certain level of banking sector development (Arcand et al., 2012, Al-Moulani\& Alexiou,2017).Thus, identifying the 
optimal levels of banking sector development is crucial for many countries striving to maximise the positive contribution of their banking sector to economic growth.

In light of the new evidence discussed above, this study apart from exploring the financial channel through which longterm economic growth is stimulated, it also provides benchmarking models that assess the status of the banking sector depth in a country vis-à-vis other countries where the banking sector inter alia is the most significant contributory factor to economic growth.

The rest of the paper is organised as follows. Section 2explores the extant literature on both the determinants of banking sector development as well as on benchmarking whilst section 3elaborates on the data, variables and methodological framework adopted in the empirical investigation. Section 4presents the empirical results whilst section 5 discusses the relevance of the generated evidence. Finally, section 6provides some concluding remarks.

\section{Literature Review}

\section{Banking Sector Development Determinants}

The close association between financial sector development and economic activity is undoubtedly a relationship that merits particular attention (Ang 2008). According to Kutan et al. (2017, p.228) 'financial market development promotes the mobilization of savings and their allocation to high-return projects'. The current debate on the financegrowth nexus has spawned a whole new empirical research that purports to shed additional light on the extant relationship between financial sector development and economic growth (see Aghion and Howitt 2009). For Vogiazas et al. (2018) however, the existing evidence on the empirical relationship between financial sector development and economic growth remains, to a certain extent, inconclusive.

Bagehot (1873) and Schumpeter (1911) were potentially two of the first academics to provide insightful arguments on the implications of the relationship between finance and growth. In particular, Bagehot (1873) outlined the conditions under which banks through funding productive investment could promote economic growth whilst Schumpeter (1911) was of the view that financial services are instrumental in stimulating economic activity. On the causal dimension however, Robinson (1952) argued that financial development follows growth thus suggesting that enterprise is the leading factor. According to Alexiou, et al. (2018, p.156), 'although growth may be constrained by credit creation in less developed financial systems, in more sophisticated systems finance is viewed as an endogenous response to demand requirements'.

The banking sector development literature suggest that the sector's development is influenced inter aliaby factors related to the governance, institutional and legal settings, the macroeconomic environment, and the sector structure. Amidst a number of macroeconomic factors that affect the development of the banking sector, inflation, trade openness, capital liberalisation, and international financial integration have been regarded as the key determinants. In particular, Boyd et al. (2001) using a dynamic panel approach find that inflation is inversely related to banking sector development. In particular, the evidence generated suggests that low to moderate inflation rates are negatively associated with banking sector depth measures, such as bank credit to the private sector, bank assets, and bank liabilities-to-GDP ratios.

Rajan and Zingales (2003) argue that the competition-enhancing effects of financial development would jeopardise the economic rents exploited by the incumbents under the current competition environment. They maintain that trade and capital account liberalisation align the incumbent firms' and financial intermediaries' interest with financial development as the benefits of liberalisation offset the costs associated with the loss in economic rents. Huang and Temple (2005) however, find that trade promotes banking sector development in higher-income countries but not the lower-income countries. For more on trade and capital account liberalisation see for instance Almarzoqi et al. (2015), Elsherif(2015), Baltagi et al. (2009), Chen et al. (2016), David et al. (2015) and Ahmed (2016).

Additional factors such as financial repression, regulations, and the level of the sector maturity are also deemed to be instrumental in determining financial sector development. More specifically, Bencivenga and Smith (1992) present a theoretical model in which high reserve requirements lead to the development of an informal financial sector that coexists with the formal sector and is not subject to such requirements. The model demonstrates that financial liberalisation results in welfare gains as funds shift from the informal to the formal sector that provides superior risk sharing. On a different study however, Asano (1999) provides evidence for the Australian economy according to which the country's financial deregulation of the 1980's did not appear to significantly affect the relationship between real output, real balances and nominal interest rate in the long run. 
Roubini and Sala-i-Martin (1992) contend that some governments tend to repress the financial sector to attain inflationary revenue as financial repression induces private agents to carry larger stocks of nominal money, hence, indicating that such policies reduce the amount of services provided by the financial sector to the economy. Moreover, Barth et al. (2004) report evidence on the basis of which regulations restricting banks from engaging in investment banking, insurance, and real estate activities are negatively associated with the level of banking sector depth. They also find a positive connection between private monitoring - measured by indices related to external auditing, credit rating, and accounting standards - and banking sector depth.

Bahadir and Valev(2015) argue that countries with lower initial levels of financial development experience faster credit growth. In this context, there is a financial development convergence process whereby countries with less developed banking sectors see their sectors develop at a faster pace than countries with more developed sectors.

On the significant role that institutions play on financial sector development, Acemoglu and Johnson (2005) show that the contracting and property rights institutions' proxies are positively associated with the credit to private sector to GDP ratio whilst Chinn and Ito (2006) find that the level of creditors' protection is positively associated with the stock market turnover and credit to private sector to GDP. Similarly, Djankov et al. (2007) investigating the impact of legal creditor rights and creditor registries on the banking sector depth find that improvement in creditor rights or the introduction of a creditor registry is followed by an increase in the banking sector depth. In the same spirit, Ayadi et al. (2013)contend that strong legal institutions, good democratic governance and adequate implementation of financial reforms, are instrumental in the development of a strong banking sector.

Le et al.(2015)argue "that better governance and institutional quality foster financial sector development in developing economies while economic growth and trade openness are key determinants of financial depth in developed economies" (p. 1047). Finally, Cherif and Dreger (2016)in a study on the financial development in the Middle East and North Africa (MENA)region, find that higher levels of corruption deter significantly the development of the banking sector.

\subsection{Benchmarking Banking Sector Development}

The extant literature employs both theoretical and empirical models in benchmarking the banking sector development in order to identify the optimal level of the sectors' development. Beck (2014) contends that non-linear finance-growth nexus and the potential negative consequence of over-developed financial sector on economic growth raise the question about the optimal sector size. He argues that research ought to identify the Goldilocks level of financial deepening that is not "too cold" or "too hot" for the economy.

One of the first theoretical research papers that consider the optimal level of financial development is that of Beck and de la Torre (2006) where the concept of 'access possibility frontier' was introduced i.e. the maximum equilibrium outreach in terms of access to credit that is prudently achievable given the state variables.

Following the work of Beck et al. (2008) and Čihák et al. (2012)on the dimensions of financial development, Beck et al. (2012) and Beck and Feyen(2013)advance the concept of the 'access possibility frontier' to what is known as 'the financial possibility frontier'. The latter is a broader concept that is defined as "the maximum sustainable depth (e.g., credit or deposit volumes), outreach (e.g., share of population reached) or breadth of a financial system (e.g., diversity of domestic sources of long-term finance) that can be realistically achieved at a given point in time" (Beck et al., 2012, p. 42, italics in the original). The state variables that influence the financial possibility frontier are structural variables (such as income, savings, and population density), macroeconomic management and credibility, legal and informational frameworks, prudential oversight, technology and infrastructure availability, and socio-economic factors. Beck and Feyen(2013) illustrate that the financial possibility frontier can be operationalized using a benchmarking exercise developed by Beck et al. (2008) and de la Torre et al. (2011). The benchmarking, however, is not equivalent to the frontier as it fails to consider the long-term institutional characteristics of countries, according to Beck and Feyen(2013). The benchmark rather represents the level of financial development predicted by the structural country characteristics.

Two empirical studies that benchmark financial sector developments using approaches similar to that of the financial possibility frontier are those of de la Torre et al. (2011) and Barajas et al. (2013). Under the assumption that the development of the financial sector exacerbates market failures and consequently undermines financial stability, de la Torre et al.,(2011) explore the financial development in Latin America and the Caribbean (LAC). The paper utilises a two-stage approach to benchmark the financial sectors. 
First, financial development indicators (including the credit to private sector, bank domestic deposits, and bank nondeposit funding to GDP ratios) are regressed on indicators of contract enforcement, legal rights, credit information property rights, and credit crises, as well as other controlling variables, using a global database for the period 19802008 and quantile (median) regression models. Then the cross-sectional estimate over medians is compared to the financial development levels of the LAC region over time. The results show that the banking sector in LAC is considerably underdeveloped with past financial turbulences explaining most of its underdevelopment.

In addition, Barajas et al. (2013)apply the financial possibility frontier concept to assess the financial performance across countries. The paper utilises the concept via a benchmarking method in which the actual levels of financial development are compared with predicted levels by the structural characteristics. Barajas et al.(2013) follow AlHussainy et al. (2011) by regressing the credit to private sector to GDP ratio, bank deposits to GDP, and stock market turnover on GDP per capita and its squared values, population density, age dependency ratio, and offshore, transition and oil-exporting countries' dummy variables. The difference between the actual level of financial sector depth measures and their values predicted by the latter model are computed for each country. The authors subsequently regress the differences in the credit to private sector to GDP measure on macroeconomic, market structure, regulatory policy, and institutional variables.

By using OLS methodology and data for 150 countries over the period from 1975 to 2005, Barajas et al. (2013)show that countries with lower inflation rates, higher remittance inflows, and more rapid previous growth rates, tend to outperform other countries by obtaining lower gaps relative to their structural benchmarks. The findings are similar to economies where restrictions on foreign banks are fewer and the share of government owned banks is lower.

In sketch of the above arguments, it becomes apparent that the few empirical papers that benchmark the development of the sector for different countries focus solely on the depth element. Further investigation onthe banking sector's development benchmarking in terms of access, efficiency, and stability is therefore warranted.

\section{Data, Variables and Methodology}

The paper uses a database that consists of 214 countries spanning over the period of 1960to 2016. It should be stressed that our intention was to incorporate a longer timespan but due to availability of data we had to treat 2016 as a cut-off point.The benchmarking models employed here, however, reduce the sample number to 184 countries. The dependent variables include real GDP per capita, real gross national income (GNI) per capita, gross capital formation to GDP ratio, and private sector gross capital formation to GDP ratio (the last two hereafter referred to as the investment to GDP and private sector investment to GDP ratios respectively). The variables are selected as proxies for economic growth. The source of all the dependent variables is the World Development Indicators database of the World Bank.

As proxies for the measures of banking sector depth we use the credit to private sector to GDP, bank assets to GDP, bank liabilities to GDP, money and quasi money (M2) to GDP, and liquid liabilities to GDP ratios (hereafter the last two indicators are referred to as money supply to GDP and broad money supply to GDP ratios accordingly). Finally, the set of the control variables consists of initial level of economic growth measures, rate of inflation, government consumption, level of education, trade openness, and foreign investment. All the independent variables, with the exception of the bank assets to GDP and the bank liabilities to GDP ratios, are obtained from the World Development Indicators database (see Data Appendix)

\subsection{Measures Employed in the Determinants of Banking Sector Depth Models}

The variables associated with the determinants of banking sector depth models can be divided into four groups. The first consists of the banking sector depth variables presented in the previous subsection and are included in the models as the dependent variables. The second group of measures is the banking efficiency, stability, and competition group, which includes variables associated with other banking sector development dimensions and the banking market structure. The third category is the macroeconomic and demography, while the fourth is the governance, institutional and legal framework.

The first variable in the banking sector depth group is the credit to private sector to GDP ratio. This ratio is the most employed in the financial sector development determinant and benchmarking literature (Baltagi et al., 2009; Barth et al., 2004; Beck \& Feyen, 2013; Boyd et al., 1996, to name a few). The second and third measures of banking sector depth are the bank assets to GDP and bank liabilities to GDP ratios. Research in the literature employing the bank assets to GDP ratio include inter alia Beck et al. (2008), Bhattacharyya \& Hodler(2014), and Boyd et al. (2001) whereas studies 
utilising the bank liabilities to GDP ratios include Beck et al. (2003), Boyd et al. (1996), and Huang (2010b). The last variable is the money supply to GDP ratio. The money supply to GDP ratio is considered to be a broad measure of banking sector depth and is employed in the literature by Bhattacharyya and Hodler(2010) and Graff and Karmann (2006).

Bank stability, efficiency and competition indicators form the first group of explanatory variables. The stability measures included here are the z-score and the credit to bank deposits ratio. The z-score measures the buffer of a countries' banking sector relative to the volatility of its returns. It is aimed at calculating the commercial banking system's probability of default. In the literature, de la Torre et al. (2011) use the banks' capital adequacy as a banking sector stability variable to explain the variation in the banking sector depth levels among the LAC countries. Čihák et al.,(2012) assess the banking sector efficiency by measuring the cost of intermediating credit. The two market efficiency variables considered here are the bank's interest rate margin and cost to income ratio. The bank net interest margin is used by de la Torre et al. (2011)as a determinant of banking sector development. No other study in the banking sector development determinant literature to our knowledge considers the cost to income ratio as an explanatory variable. Finally, the paper captures the banking sector competition using the bank concentration and the 5bank asset concentration measures. In the literature, Barajas et al. (2013)include the 5-bank asset concentration along with the Lerner Index of market power as market structure indicators to explain the gap between the actual level of banking sector development and the predicted level associated with their benchmarking model.

The second set of explanatory variables are those related to macroeconomic and demography. The GDP per capita is one of the extensively used measures in explaining the level of banking sector development in the literature. Studies in thisarea, however, overlook the structure of the economy that contributes to the development of the banking sector. We use the ratios of manufacturing value added, industry value added, and services value added-to- GDP to evaluatewhether economies that are more dependent on services, vis-à-vis manufacturing, experience different levels of banking sector development. Following Beck et al.'s(2012) theoretical model which contends that savings is one of the structural variables that influence the level of financial deepening, the paper includes the ratios of gross savings to GDP. In the same vein, the household final consumption to GDP is also included in the macroeconomic and demography group; here, consumption is considered, as opposed to savings within the economy. In line with Baltagi et al. (2009), Chinn and Ito (2006), Girma and Shortland (2004), Herger et al. (2008) and Huang (2010a, 2010b) we also employ trade openness in our estimation. In the literature, scholars also extensively employ the measures of inflation and population as explanatory variables. In this paper, the consumer price index (CPI)and the total population are used as measures of the inflation rate and the population size.

The final explanatory variables group is the governance, institutional, and legal category. The paper employ indices related to voice and accountability, political stability and absence of violence, rule of law, control of corruption, government effectiveness, regulatory quality, as well as a British Law dummy variable as a proxy for the legal origin (for more on this see for instance Acemoglu and Johnson; Barajas et al. 2013).

\subsection{Models Specifications}

In this study, there are two sets of models that have been estimated. The first set includes the models reflecting the relationship between banking sector depth and long-term economic growth using different measures' combinations and are estimated with the mixed effects method whilst the second set of models consists of dynamic panel data models that explores the determinants of banking sector's depth. For the second set of models we opted for the system GMM estimator to overcome inherent problems encountered in the estimation of dynamic panel data models (see Rodman, 2006).

The general regression equation used for the estimation of the first set of models is couched in the following terms:

$$
y_{i, t}=\alpha_{i}+\beta_{i, x_{t-1}}+\gamma_{i} z_{t-1}+\varepsilon_{i, t}
$$

where the economic growth measure $\left(y_{i, t}\right)$ is regressed on a constant $\left(\alpha_{i}\right)$, the first-time lagged measure of banking sector depth $\left(x_{t-1}\right)$, and the first lagged values of the controlling variables $\left(z_{t-1}\right)$. The term $\varepsilon_{i, t}$ is an error term. The equation is designed to capture the relationship between the banking sector depth and economic growth while controlling for the initial levels of income, inflation rate, education, government consumption, trade openness, and foreign direct investment(FDI). For the purpose of ranking countries by the effect of the banking sector depth on 
economic growth, linear models specifications are employed.To estimate the random effects for each country, equation1 is re-written as:

$$
y_{i, t}=\alpha_{i}+\beta_{i} x_{t-1}+\gamma_{i} z_{t-1}+u_{\alpha_{i}}+u_{\beta_{i}}+\varepsilon_{i, t}
$$

Equation2 is estimated to obtain the BLUPs of the random effects. The BLUPs show the variation in the intercept and the beta coefficient for each country (Torres-Reyna, 2015).

For the second set of models, the general regression equation is given by:

$$
y_{i, t}=\alpha_{i}+\beta_{j} y_{i, t-1}+\gamma_{j} x_{i, t-1}+\delta_{j} z_{i, t}+\varepsilon_{t}
$$

where the banking sector depth measure $\left(y_{i, t}\right)$ is regressed on a constant $\left(\alpha_{i}\right)$, its first time lagged value $\left(y_{i, t-1}\right)$, the first time lagged values of the banking sector and macroeconomic variables $\left(x_{i, t-1}\right)$, and a set of population and governance measures $\left(z_{i, t}\right)$. In particular, the banking sector variables consist of, the credit to deposit ratio, the net interest margin, the cost-to-income ratio, the z-score, the bank concentration ratio, and the top-five banks' concentration ratio; the macroeconomic variables consist of the real GDP per capita, CPI, and the ratios of industry value-added, manufacturing value-added, services value-added, consumption, trade, and savings-to-GDP ratio. The governance variables consist of the six Worldwide Governance Indicators and an English law dummy variable. In passing, it should be mentioned that equation 3purports to identify the banking sector determinants in a dynamic panel data setting whilst controlling for population and governance effects (see Data Appendix).

In identifying the countries in which the banking sector depth has the highest positive effect on long-term economic growth we estimate equation 2 using the mixed effects approach using different combinations of five banking sector depth proxies and the four economic growth measures. The models are estimated using data for 184 countries from 1964 to 2015 averaged over 10 non-overlapping five-year time periods.

The statistical significance of each model is evaluated by considering the z-statistic probability values associated with the banking sector depth measure coefficients and the likelihood restriction test.The banking sector depth variable is considered statistically significant when the reported z-statistic probability value is below $10 \%$. The set of controlling variables are included in all the models, regardless of their statistical significance, to ensure that various models account for differences among countries owing to such variables. The likelihood ratio test is required to verify whether the mixed effects model offers significant improvement over the linear regression model with the fixed effects only (Hamilton, 2012). A probability value associated with the likelihood ratio test that is below 10\% indicates that the mixed effects model provides improvement over the fixed effects model.

After identifying the statistically significant banking-growth nexus models, the predicted slope coefficient for each country is obtained. The predicted slope coefficient variation for each country is derived using the iterative technique of Bates and Pinheiro (1998) and indicates whether the predicted slope coefficients are smaller or larger than the slope coefficient of the whole sample. The slope variation for individual countries along with the sample slope coefficient can be employed to calculate the predicted banking sector depth slope coefficient for each country. The latter informs the paper about the predicted effect of the banking sector deepening on long-term economic growth in each country.

We then rank the countries in accordance with the significance of their banking sector for economic growth from the highest to the lowest hence, obtaining a list for each statistically significant model. Once the countries in the top quartile of each list are identified and assigned one point each, then the point for each country are added up to obtain a raking of countries from those with the highest to the lowest points. Finally, based on the average size of all the lists, the top quartile countries in the list with the aggregated points are selected as proxies for the countries with the most influential banking sectors for economic growth. The data for the countries in the top quartile are subsequently used to estimate the banking sector depth model.

Next step is the estimation of equation 3 using the system GMM estimator for the five banking sector depth proxies. In line with the methodological framework adopted, the selected models are required to satisfy the second order serial correlation and the joint validity of the instrument's tests. The second-order serial correlation is a test of the validity of the included lags in the model. The Hansen over-identification test is conducted to establish the joint validity of the instruments in the GMM models (Roodman, 2009a, 2009b).(For an extensive review of the two-step estimation with the corrected errors see Windmeijer,2005). Finally, the selected banking sector depth determinant models are set as the benchmark models that are utilised in assessing the status of the banking sector depth. 


\section{Results}

4.1 Banking-Growth Nexus using the Mixed Effects Models

The mixed effects models are estimated using all the different combinations given four different economic growth indicators and five banking sector depth measures. The results of the 20 estimated models are reported in tables I and II. On the basis of the estimated results, the banking-growth nexus is found to be statistically significant at the $10 \%$ confidence level in models $1,3,4,5,6,8,9,1015$, and 18 .

Table I: Banking-Growth Nexus Mixed Effects Models 1 to 5

\begin{tabular}{|c|c|c|c|c|c|}
\hline Model Number & 1 & 2 & 3 & 4 & 5 \\
\hline Dependent variable & Real GDP per Capita & & & & \\
\hline $\begin{array}{l}\text { Credit to Private Sector to } \\
G D P_{t-1}\end{array}$ & $\begin{array}{l}0.129 * * * \\
(0.000)\end{array}$ & & & & \\
\hline Bank Assets to GDP $P_{t-1}$ & & $\begin{array}{l}0.0014 \\
(0.222)\end{array}$ & & & \\
\hline Bank Liabilities to $G D P_{t-1}$ & & & $\begin{array}{l}0.0561 * * * \\
(0.005)\end{array}$ & & \\
\hline Money Supply to $G D P_{t-1}$ & & & & $\begin{array}{l}0.2044 * * * \\
(0.004)\end{array}$ & \\
\hline $\begin{array}{ll}\text { Broad Money Supply to } \\
\text { GDP }_{t-1}\end{array}$ & & & & & $\begin{array}{l}0.1545^{* *} \\
(0.050)\end{array}$ \\
\hline $\begin{array}{l}\text { Initial Real GDP per } \\
\text { Capitat }_{t-1}\end{array}$ & $\begin{array}{l}0.194 \mathrm{E}-4 * * * \\
(0.000)\end{array}$ & $\begin{array}{l}0.403 \mathrm{E}-4 * * * \\
(0.000)\end{array}$ & $\begin{array}{l}0.34 \mathrm{E}-04 * * * \\
(0.000)\end{array}$ & $\begin{array}{l}0.178 \mathrm{E}-4 * * * \\
(0.000)\end{array}$ & $\begin{array}{l}0.329 \mathrm{E}-4 * * * \\
(0.000)\end{array}$ \\
\hline $\begin{array}{l}\text { Gross Secondary School } \\
\text { Enrolment }_{t-1}\end{array}$ & $\begin{array}{l}0.2316^{* * * *} \\
(0.010)\end{array}$ & $\begin{array}{l}0.3418 * * * \\
(0.004)\end{array}$ & $\begin{array}{l}0.3321 * * * \\
(0.002)\end{array}$ & $\begin{array}{l}0.1966^{* * * *} \\
(0.004)\end{array}$ & $\begin{array}{l}0.1742 * * * \\
(0.006)\end{array}$ \\
\hline Inflation Rate $_{t-1}$ & $\begin{array}{c}-0.1638 * * * \\
(0.004)\end{array}$ & $\begin{array}{l}-0.1544 * * * \\
(0.007)\end{array}$ & $\begin{array}{l}-0.1461^{* * * *} \\
(0.008)\end{array}$ & $\begin{array}{l}-0.1811^{* * *} \\
(0.001)\end{array}$ & $\begin{array}{l}-0.1068 * * \\
(0.004)\end{array}$ \\
\hline $\begin{array}{l}\text { Government Consumption } \\
\text { to } G D P_{t-1}\end{array}$ & $\begin{array}{l}-0.0142 \\
\quad(0.142)\end{array}$ & $\begin{array}{l}-0.1527 * * * \\
(0.008)\end{array}$ & $\begin{array}{l}-0.1942 * * * \\
(0.005)\end{array}$ & $\begin{array}{l}-0.103^{* * *} \\
(0.008)\end{array}$ & $\begin{array}{l}0.1138^{*} \\
(0.068)\end{array}$ \\
\hline$F D I$ to $G D P_{t-1}$ & $\begin{array}{r}0.0283 * * * \\
(0.008)\end{array}$ & $\begin{array}{l}0.0173^{*} \\
(0.056)\end{array}$ & $\begin{array}{l}0.014 \\
(0.115)\end{array}$ & $\begin{array}{l}0.0206 * * * \\
(0.007)\end{array}$ & $\begin{array}{l}0.0219 * \\
(0.061)\end{array}$ \\
\hline Trade to $G D P_{t-1}$ & $\begin{array}{r}0.2295^{* * *} \\
(0.001)\end{array}$ & $\begin{array}{l}0.285^{* * *} \\
(0.001)\end{array}$ & $\begin{array}{l}0.2447 * * * \\
(0.009)\end{array}$ & $\begin{array}{l}0.2454 * * * \\
(0.008)\end{array}$ & $\begin{array}{l}0.1936^{* * * *} \\
(0.004)\end{array}$ \\
\hline Constant & $\begin{array}{l}5.6085^{* * *} \\
(0.000)\end{array}$ & $\begin{array}{l}5.6278 * * * \\
(0.00)\end{array}$ & $\begin{array}{l}5.9261^{* *} \\
(0.041)\end{array}$ & $\begin{array}{l}5.5741^{* *} \\
(0.061)\end{array}$ & $\begin{array}{l}5.3129^{*} \\
(0.083)\end{array}$ \\
\hline Observations & 644 & 583 & 564 & 625 & 234 \\
\hline Countries & 158 & 146 & 145 & 158 & 75 \\
\hline
\end{tabular}

The table reports the regression results of the mixed effects models for 184 countries. P-values are shown in parentheses, with significance levels at the $10 \%(*), 5 \%(* *)$, and $1 \%(* * *)$ levels indicated. 
Table I (continued.): Banking-Growth Nexus Mixed Effects Models 6 to 10.

\begin{tabular}{|c|c|c|c|c|c|}
\hline Model Number & 6 & 7 & 8 & 9 & 10 \\
\hline Dependent variable & \multicolumn{5}{|c|}{ Real GNI per Capita } \\
\hline Credit to Private Sector to $G D P_{t-1}$ & \multicolumn{5}{|l|}{$\begin{array}{l}0.1049 * * * \\
(0.003)\end{array}$} \\
\hline Bank Assets to $G D P_{t-1}$ & \multicolumn{5}{|c|}{$\begin{array}{l}-0.0206 \\
(0.119)\end{array}$} \\
\hline Bank Liabilities to $G D P_{t-1}$ & \multicolumn{5}{|c|}{$\begin{array}{l}0.0447 * * * \\
(0.006)\end{array}$} \\
\hline Money Supply to $G D P_{t-1}$ & & & \multicolumn{3}{|c|}{$\begin{array}{l}0.187 * * * \\
(0.008)\end{array}$} \\
\hline Broad Money Supply to $G D P_{t-1}$ & & & & & $\begin{array}{l}0.1432^{*} \\
(0.008)\end{array}$ \\
\hline Initial Real GDP per Capita $_{t-1}$ & $\begin{array}{l}0.168 \mathrm{E}-4 * * * \\
(0.000)\end{array}$ & $\begin{array}{l}0.378 \mathrm{E}-4 * * * \\
(0.000)\end{array}$ & $\begin{array}{l}0.309 \mathrm{E}-4 * * * \\
(0.000)\end{array}$ & $\begin{array}{l}0.16 \mathrm{E}-4 * * * \\
(0.000)\end{array}$ & $\begin{array}{l}0.275 \mathrm{E}-4 * * * \\
(0.000)\end{array}$ \\
\hline $\begin{array}{l}\text { Gross Secondary } \quad \text { School } \\
\text { Enrolment } t_{t-1}\end{array}$ & $\begin{array}{l}0.2164 * * * \\
(0.003)\end{array}$ & $\begin{array}{l}0.3871 * * * \\
(0.002)\end{array}$ & $\begin{array}{l}0.3837 * * * \\
(0.000)\end{array}$ & $\begin{array}{l}0.2008 * * * \\
(0.000)\end{array}$ & $\begin{array}{l}0.2103 * * * \\
(0.000)\end{array}$ \\
\hline Inflation Rate $_{t-1}$ & $\begin{array}{l}-0.1294 * * * \\
(0.000)\end{array}$ & $\begin{array}{l}-0.1398 * * * \\
(0.000)\end{array}$ & $\begin{array}{l}-0.1296 * * * \\
(0.000)\end{array}$ & $\begin{array}{l}-0.1615^{* * *} \\
(0.000)\end{array}$ & $\begin{array}{l}-0.0585 \\
(0.000)\end{array}$ \\
\hline $\begin{array}{l}\text { Government Consumption to } G D P_{t-} \\
{ }_{1}\end{array}$ & $\begin{array}{l}-0.0101 \\
(0.154)\end{array}$ & $\begin{array}{l}-0.1549 * * * \\
(0.000)\end{array}$ & $\begin{array}{l}-0.2107 * * * \\
(0.000)\end{array}$ & $\begin{array}{l}-0.1017 * * \\
(0.050)\end{array}$ & $\begin{array}{l}0.1156 \\
(0.181)\end{array}$ \\
\hline FDI to $G D P_{t-1}$ & $\begin{array}{l}0.0271 * * * \\
(0.000)\end{array}$ & $\begin{array}{l}0.0041 \\
(0.112)\end{array}$ & $\begin{array}{l}0.0041 \\
(0.213)\end{array}$ & $\begin{array}{l}0.0137 \\
(0.129)\end{array}$ & $\begin{array}{l}0.0237 * \\
(0.052)\end{array}$ \\
\hline Trade to $G D P_{t-1}$ & $\begin{array}{l}0.3185^{* * * *} \\
(0.001)\end{array}$ & $\begin{array}{l}0.3135^{* * * *} \\
(0.003)\end{array}$ & $\begin{array}{l}0.2559 * * * \\
(0.005)\end{array}$ & $\begin{array}{l}0.3081 \text { *** } \\
(0.001)\end{array}$ & $\begin{array}{l}0.26 * * * \\
(0.004)\end{array}$ \\
\hline Constant & $\begin{array}{l}5.3826 * * * \\
(0.000)\end{array}$ & $\begin{array}{l}5.4398 * * * \\
(0.001)\end{array}$ & $\begin{array}{l}\text { 5.7982*** } \\
(0.005)\end{array}$ & $\begin{array}{l}5.3795 * * * \\
(0.008)\end{array}$ & $\begin{array}{l}5.0239 \text { *** } \\
(0.05)\end{array}$ \\
\hline Observations & 496 & 444 & 430 & 477 & 197 \\
\hline Countries & 123 & 113 & 111 & 123 & 63 \\
\hline
\end{tabular}

The table reports the regression results of the mixed effects models for 184 countries. P-values are shown in parentheses, with significance levels at the $10 \%(*), 5 \%(* *)$, and $1 \%(* * *)$ levels indicated.

The individual countries' slope coefficients associated with the statistically significant models are then used to rank the countries accordingly - i.e.in accordance with the size of their slope coefficient in each model — from the highest to the lowest. By assigning a point to each country in the top quartile, summing the points for each country, and ranking countries by the number of points, we can identify countries in which the banking sector exerts the highest positive effect on long-term economic growth. Using the average number of countries in each statistically significant mixed effect model, table A1 in the appendix lists the names and scores of the countries in the top quartile. 
Table II: Banking-Growth Nexus Mixed Effects Models 11 to 15

\begin{tabular}{|c|c|c|c|c|c|}
\hline Model Number & 11 & 12 & 13 & 14 & 15 \\
\hline & \multicolumn{5}{|c|}{ Private Investment to GDP Ratio } \\
\hline Credit to Private Sector to $G D P_{t-1}$ & \multicolumn{5}{|l|}{$\begin{array}{l}-0.0447 * * \\
(0.045)\end{array}$} \\
\hline Bank Assets to $G D P_{t-1}$ & \multicolumn{5}{|c|}{$\begin{array}{l}-0.0143^{* *} \\
(0.029)\end{array}$} \\
\hline Bank Liabilities to $G D P_{t-1}$ & \multicolumn{5}{|c|}{$\begin{array}{l}0.005^{* *} \\
(0.029)\end{array}$} \\
\hline Money Supply to $G D P_{t-1}$ & & & \multicolumn{3}{|c|}{$\begin{array}{l}-0.0295 * * \\
(0.065)\end{array}$} \\
\hline Broad Money Supply to GDP $P_{t-1}$ & & & & & $\begin{array}{l}-0.2258^{*} \\
(0.053)\end{array}$ \\
\hline Initial Real GDP per Capita $_{t-1}$ & $\begin{array}{l}0.148 \mathrm{E}-4 \\
(0.255)\end{array}$ & $\begin{array}{l}-0.41 \mathrm{E}-5 \\
(0.228\end{array}$ & $\begin{array}{l}-0.104 \mathrm{E}-5 \\
(0.234)\end{array}$ & $\begin{array}{l}0.141 \mathrm{E}-4 \\
(0.224)\end{array}$ & $\begin{array}{l}0.421 \mathrm{E}-4 \\
(0.323)\end{array}$ \\
\hline $\begin{array}{ll}\text { Gross Secondary } & \text { School } \\
\text { Enrolment } t-1 & \\
\end{array}$ & $\begin{array}{l}0.1322 * * * \\
(0.007)\end{array}$ & $\begin{array}{l}0.1674 * * * \\
(0.003)\end{array}$ & $\begin{array}{l}0.1511 * * * \\
(0.002)\end{array}$ & $\begin{array}{l}0.1197 * * \\
(0.049)\end{array}$ & $\begin{array}{l}0.0719 \\
(0.174)\end{array}$ \\
\hline Inflation Rate $_{t-1}$ & $\begin{array}{l}-0.1336^{* *} \\
(0.058)\end{array}$ & $\begin{array}{l}-0.0936 \\
(0.159)\end{array}$ & $\begin{array}{l}-0.0871 \\
(0.166)\end{array}$ & $\begin{array}{l}-0.1347^{*} \\
(0.061)\end{array}$ & $\begin{array}{l}-0.2121^{* *} \\
(0.041)\end{array}$ \\
\hline $\begin{array}{l}\text { Government Consumption to } G D P_{t-} \\
t\end{array}$ & $\begin{array}{l}-0.0605 \\
(0.187)\end{array}$ & $\begin{array}{l}0.0037 \\
(0.286)\end{array}$ & $\begin{array}{l}0.003 \\
(0.191)\end{array}$ & $\begin{array}{l}-0.0326 \\
(0.339)\end{array}$ & $\begin{array}{l}-0.2132 \\
(0.154)\end{array}$ \\
\hline FDI to $G D P_{t-1}$ & $\begin{array}{l}0.039 * \\
(0.052)\end{array}$ & $\begin{array}{l}0.0436^{* *} \\
(0.041)\end{array}$ & $\begin{array}{l}0.0445^{*} \\
(0.053)\end{array}$ & $\begin{array}{l}0.0266 \\
(0.122)\end{array}$ & $\begin{array}{l}0.001 \\
(0.125)\end{array}$ \\
\hline Trade to $G D P_{t-1}$ & $\begin{array}{l}0.0382 \\
(0.183)\end{array}$ & $\begin{array}{l}0.0364 \\
(0.286)\end{array}$ & $\begin{array}{l}0.028 \\
(0.586)\end{array}$ & $\begin{array}{l}0.0776 \\
(0.281)\end{array}$ & $\begin{array}{l}0.3019 * * \\
(0.022)\end{array}$ \\
\hline Constant & $\begin{array}{l}2.2978^{* * *} \\
(0.000)\end{array}$ & $\begin{array}{l}1.9528^{*} \\
(0.093)\end{array}$ & $\begin{array}{l}2.0097 * * \\
(0.048)\end{array}$ & $\begin{array}{l}2.0916^{* *} \\
(0.039)\end{array}$ & $\begin{array}{l}2.4719 * * * \\
(0.000)\end{array}$ \\
\hline Observations & 291 & 266 & 254 & 292 & 128 \\
\hline Countries & 80 & 74 & 72 & 80 & 44 \\
\hline
\end{tabular}

The table reports the regression results of the mixed effects models for 184 countries. P-values are shown in parentheses, with significance levels at the $10 \%(*), 5 \%(* *)$, and $1 \%(* * *)$ levels indicated. 
Table II (continued): Banking-Growth Nexus Mixed Effects Models 16 to 20

\begin{tabular}{|c|c|c|c|c|c|}
\hline \multirow[t]{2}{*}{ Model Number } & \multicolumn{2}{|l|}{16} & \multicolumn{2}{|l|}{19} & \multirow[t]{2}{*}{20} \\
\hline & Investment to & SDP Ratio & & & \\
\hline $\begin{array}{l}\text { Credit to Private Sector } \\
\text { to } G D P_{t-1}\end{array}$ & $\begin{array}{l}-0.029 \\
(0.223)\end{array}$ & & & & \\
\hline Bank Assets to GDP $P_{t-1}$ & & $\begin{array}{l}0.0008 \\
(0.514)\end{array}$ & & & \\
\hline Bank Liabilities to $G D P_{t-1}$ & & & $\begin{array}{l}-0.0248^{*} \\
(0.051)\end{array}$ & & \\
\hline Money Supply to $G D P_{t-1}$ & & & & $\begin{array}{l}0.0231 \\
(0.233)\end{array}$ & \\
\hline $\begin{array}{l}\text { Broad Money Supply to } \\
G D P_{t-1}\end{array}$ & & & & & $\begin{array}{l}-0.0436 \\
(0.171)\end{array}$ \\
\hline $\begin{array}{l}\text { Initial Real GDP per } \\
\text { Capitat }_{t-1}\end{array}$ & $\begin{array}{l}-0.557 \mathrm{E}-5^{* *} \\
(0.046)\end{array}$ & $\begin{array}{l}-0.782 \mathrm{E}-5^{* * *} \\
(0.000)\end{array}$ & $\begin{array}{l}-0.5 \mathrm{E}-577 * * \\
(0.046)\end{array}$ & $\begin{array}{l}-0.626 \mathrm{E}-5 * * * \\
(0.000)\end{array}$ & $\begin{array}{l}-0.131 \mathrm{E}-5 \\
(0.406)\end{array}$ \\
\hline $\begin{array}{l}\text { Gross Secondary School } \\
\text { Enrolment }_{t-1}\end{array}$ & $\begin{array}{l}0.0511^{*} \\
(0.063)\end{array}$ & $\begin{array}{l}0.051^{*} \\
(0.093)\end{array}$ & $\begin{array}{l}0.0545 * * \\
(0.028)\end{array}$ & $\begin{array}{l}0.0315 \\
(0.567)\end{array}$ & $\begin{array}{l}0.0093 \\
(0.746)\end{array}$ \\
\hline Inflation Rate $_{t-1}$ & $\begin{array}{l}-0.1235^{* * *} \\
(0.000)\end{array}$ & $\begin{array}{l}-0.1179 * * * \\
(0.000)\end{array}$ & $\begin{array}{l}-0.1224 * * * \\
(0.000)\end{array}$ & $\begin{array}{l}-0.1189 * * * \\
(0.000)\end{array}$ & $\begin{array}{l}-0.0612 \\
(0.126)\end{array}$ \\
\hline $\begin{array}{l}\text { Government } \\
\text { Consumption to GDP } P_{t-1}\end{array}$ & $\begin{array}{l}-0.0426 \\
(0.447)\end{array}$ & $\begin{array}{l}-0.0004 \\
(0.447)\end{array}$ & $\begin{array}{l}-0.0036 \\
(0.347)\end{array}$ & $\begin{array}{l}-0.0443 \\
(0.146)\end{array}$ & $\begin{array}{l}-0.0596 \\
(0.495)\end{array}$ \\
\hline FDI to $G D P_{t-1}$ & $\begin{array}{l}0.0129 \\
(0.322)\end{array}$ & $\begin{array}{l}0.0142 \\
(0.283)\end{array}$ & $\begin{array}{l}0.0148 \\
(0.271)\end{array}$ & $\begin{array}{l}0.0099 \\
(0.228)\end{array}$ & $\begin{array}{l}0.0039 \\
(0.216)\end{array}$ \\
\hline Trade to $G D P_{t-1}$ & $\begin{array}{l}0.0647 \\
(0.343)\end{array}$ & $\begin{array}{l}0.0293 \\
(0.644)\end{array}$ & $\begin{array}{l}0.0359 \\
(0.143)\end{array}$ & $\begin{array}{l}0.0531 \\
(0.142)\end{array}$ & $\begin{array}{l}0.1324 * \\
(0.479)\end{array}$ \\
\hline Constant & $\begin{array}{l}2.8993 * * * \\
(0.001)\end{array}$ & $\begin{array}{l}2.8666 * * * \\
(0.000)\end{array}$ & $\begin{array}{l}2.8607 * * * \\
(0.001)\end{array}$ & $\begin{array}{l}2.8543 * * * \\
(0.001)\end{array}$ & $\begin{array}{l}2.8269 * * * \\
(0.002)\end{array}$ \\
\hline Observations & 500 & 447 & 433 & 481 & 200 \\
\hline Countries & 123 & 113 & 111 & 123 & 63 \\
\hline
\end{tabular}

The table reports the regression results of the mixed effects models for 184 countries. P-values are shown in parentheses, with significance levels at the $10 \%(*), 5 \%(* *)$, and $1 \%(* * *)$ levels indicated.

\subsection{Banking Sector Depth Determinants: System GMM for Dynamic Panel Data Models}

To investigate the factors determining the level of banking sector depth in the economies in which the banking sector contributes the most in terms of long-term economic growth, we use the data that correspond to the countries listed in table $\mathrm{A} 1$ in the appendix.

The banking sector depth measures are regressed on a broad set of factors associated with the economic structure, growth, demography, banking sector stability, efficiency and competition, as well as governance, institutional and legal settings. Table III reports the results of the reduced models using the general-to-specific approach. 
Table III: Banking Sector Depth Determinant Models

\begin{tabular}{|c|c|c|c|c|}
\hline Model Number & 21 & 22 & 23 & 24 \\
\hline & $\begin{array}{l}\text { Bank Credit to Private } \\
\text { Sector to GDP Ratio }\end{array}$ & $\begin{array}{l}\text { Bank Assets to } \\
\text { GDP Ratio }\end{array}$ & $\begin{array}{l}\text { Bank Liabilities } \\
\text { to GDP Ratio }\end{array}$ & $\begin{array}{l}\text { Money Supply to } \\
\text { GDP Ratio }\end{array}$ \\
\hline $\begin{array}{l}\text { Bank Credit to Private Sector } \\
\text { to GDP } P_{t-1}\end{array}$ & $\begin{array}{l}0.9127 * * * \\
(0.000)\end{array}$ & & & \\
\hline Bank Assets to GDP $P_{t-1}$ & & $\begin{array}{l}0.6481 * * * \\
(0.001)\end{array}$ & & \\
\hline Bank Liabilities to $G D P_{t-1}$ & & & $\begin{array}{l}0.6712 * * * \\
(0.000)\end{array}$ & \\
\hline Money Supply to $G D P_{t-1}$ & & & & $\begin{array}{l}0.8814 * * * \\
(0.000)\end{array}$ \\
\hline Z-Score $_{t-1}$ & & & & $\begin{array}{l}0.1516^{*} \\
(0.000)\end{array}$ \\
\hline Net Interest Margin ${ }_{t-1}$ & & & $\begin{array}{l}-0.3296 * * \\
(0.000)\end{array}$ & \\
\hline Bank Concentration $_{t-1}$ & $\begin{array}{l}-0.1628^{*} \\
(0.089) \\
\end{array}$ & & & \\
\hline Saving to GDP Ratio ${ }_{t-1}$ & & & & $\begin{array}{l}-0.2512 * * * \\
(0.000)\end{array}$ \\
\hline Consumption to $G D P_{t-1}$ & & & & $\begin{array}{l}-0.3989 * * \\
(0.065)\end{array}$ \\
\hline Consumer Price Index $x_{t-1}$ & & $\begin{array}{l}-0.2305^{*} \\
(0.071)\end{array}$ & & \\
\hline $\begin{array}{l}\text { Political Stability \& Absence } \\
\text { of Violence }\end{array}$ & & & $\begin{array}{l}0.2568^{* *} \\
(0.031)\end{array}$ & \\
\hline Rule of Law & & $\begin{array}{l}0.3961 * * \\
(0.048)\end{array}$ & & \\
\hline Regulatory Quality & $\begin{array}{l}0.0433 * \\
(0.064)\end{array}$ & & & \\
\hline Constant & $\begin{array}{l}1.0131 * * * \\
(0.000)\end{array}$ & $\begin{array}{l}-0.7408 * * * \\
(0.000)\end{array}$ & $\begin{array}{l}0.3231 \\
(0.326)\end{array}$ & $\begin{array}{l}2.5223 * * * \\
(0.000)\end{array}$ \\
\hline Observations & 392 & 502 & 374 & 375 \\
\hline Groups & 31 & 32 & 33 & 32 \\
\hline Instruments & 27 & 34 & 31 & 29 \\
\hline $\operatorname{AR}(\mathbf{1})$ & -2.61 & -2.1 & -2.68 & -3.17 \\
\hline AR(1) p-value & 0.009 & 0.036 & 0.007 & 0.002 \\
\hline $\mathbf{A R}(2)$ & 0.312 & 0.491 & -0.381 & -0.651 \\
\hline AR(2) p-value & 0.767 & 0.626 & 0.706 & 0.515 \\
\hline $\begin{array}{l}\text { Sargan } \\
\text { Test }\end{array}$ & 34.17 & 37.37 & 57.01 & 21.86 \\
\hline Sargan p-value & 0.063 & 0.167 & 0.001 & 0.588 \\
\hline $\begin{array}{l}\text { Hansen Overidentification } \\
\text { Test }\end{array}$ & 23.02 & 30.78 & 25.78 & 19.35 \\
\hline Hansen p-value & 0.46 & 0.426 & 0.531 & 0.733 \\
\hline
\end{tabular}

Notes: The table reports the regression results of the selected System GMM for the dynamic panel data models investigating the relationship between bank sector depth measures and their determinants. All the models are based 
onthe two-step estimation procedure and the Windmeijer corrected standard error. P-values are shown inparentheses, with significance levels at the $10 \%(*), 5 \%(* *)$, and $1 \%(* * *)$ levels indicated.

The results of model number 21 indicate that the current level of credit to private sector to GDP ratio is determined by its lagged value, the level of banking sector concentration, and the regulatory quality. Furthermore, the estimation results suggest that a $1 \%$ increase in the assets of the three largest banks, as a share of the total commercial banking assets, reduces the credit to private sector to GDP ratio by $0.163 \%$. Moreover, a $0.10 \%$ improvement in the regulatory indicator - which along with the other Worldwide Governance Indicators ranges from -2.5 to 2.5 approximately results in a $0.433 \%$ increase in the credit to private sector to GDP ratio.

In the dynamic regression model investigating the factors influencing the bank assets to GDP ratio, the CPI and rule of law are statistically significant at the $10 \%$ and $5 \%$ levels of significance respectively. The slope coefficient of the CPI implies that a $10 \%$ acceleration in the inflation measure leads to a $2.305 \%$ drop in the size of the bank assets relative to the size of the economy. The results also reveal that the rule of law has a relatively considerable effect on the banking sector depth measure - i.e. a 0.10 rise in the rule of law index is expected to increase the level of bank assets to GDP ratio by $3.961 \%$. For instance, a $0.10 \%$ surge in the rule of law index is likely to lift a country's bank assets to GDP ratio from $25 \%$ to $26 \%$ ceteris paribus.

Model 23(see table III) suggests that the bank liabilities to GDP ratio is determined by its lagged level, the net interest margin, and political stability. The net interest margin of the banking sector is negatively linked to the level of the banking sector depth. The evidence obtained indicates that a $1 \%$ growth in the net interest margin is associated with a $0.330 \%$ drop in the bank liabilities to GDP ratio. In contrast, the political stability is positively associated with the banking sector depth measure. An improvement in political stability is also expected to raise the bank liabilities to GDP ratio.

In table III(model 24), the money supply-to-GDP ratio is used as the dependent variable. The results suggest that in addition to the previous reading of money supply-to-GDP ratio, the banking sector stability measured by the z-score, the levels of consumption, and the levels of savings are found to be statistically significant determinants of the banking sector depth.In particular, a $1 \%$ increase in the z-score leads to a $0.152 \%$ growth in the proportion of the money supplyto-GDP ratio.Both consumption and savings are found to be negatively associated with banking sector depth. The evidence suggests that when the consumption-to- GDP ratio level expands by $1 \%$, the money supply as a share of GDP falls by $0.399 \%$. Similarly, a $1 \%$ higher level of savings-to-GDP ratio is anticipated to drive the banking sector depth measure down by $0.251 \%$. The z-score is statistically significant at the $10 \%$ test level, whilst the consumption to GDP and savings to GDP ratios are found to be statistically significant at the 5\% and $1 \%$ test levels respectively.

In a nutshell, the findings of all the four models reported in table 4 indicate that the lagged dependent variables are all significant. In particular, the slope coefficients of the first lag of the banking sector depth measures ranged from 0.648in the model investigating the bank assets-to-GDP ratio to 0.913in the model associated with the bank credit to private sector-to-GDP ratio.

The results also reveal that a number of the banking sector depth stability, efficiency and competition variables are statistically significant in three out of four banking sector depth determinant models. In the model featuring the credit to private sector-to-GDP ratio, the level of banking sector competition measured by bank concentration is found to be significant hence suggesting that the higher competition levels the higher the sector's development. The banking sector efficiency - proxied by the net interest margin - is a determinant of the bank liabilities-to-GDP ratio in countries with banking sectors that promote long-term economic growth the most. In addition, bank stability has transpired to be an important factor that conditions financial depth in the sector. In model 24 , the z-score is found to be positively associated with the money supply to GDP ratio.

Out of the various macroeconomic and demographic variables included in the general models, three measures are found to be of statistical significance in the banking sector depth models. More specifically, CPI bears a negative sign, hence, suggesting that higher levels of inflation deter the development of the banking sector whilst both the savings-to-GDP ratio and the consumption-to-GDP ratio are found to be negatively associated with the money supply-to-GDP ratio. Finally, the variables related to governance, institutional, and legal indicators' category were found to be of great significance for economies in which the banking sector has been instrumental in precipitating the highest levels of economic growth. 


\section{Discussion}

The results associated with models 21 to 24 address the first research question by identifying the banking, macroeconomic, as well as governance and institutional factors, that determine the depth of the banking sectors in countries in which the banking-growth relationship is manifested in its highest possible level.

The first banking sector structure factor that influences the level of sector depth is competition. The results of model 21 indicate that the more competitive a banking sector is the more it is associated with higher levels of banking sector credit to private sector as share of GDP. The findings are similar to those of Barajas et al. (2013)where the data for as many as 161 countries are used to benchmark the banking sectors across the globe based on their structural characteristics. Barajas et al. (2013) show that the banking competition measured by the asset concentration of the largest five banks is negatively linked to financial deepening. However, what differentiates the results reported in this study from those of Barajas et al. (2013) is that here the bank concentration measure accounts for the largest three banks rather than the largest five banks. In fact, the 5-bank assets concentration variable is statistically insignificant across all banking sector depth determinant models. Another difference between the two studies is that this study only considers the 34 countries in the top quartile of the banking-growth relationship using a predetermined selecting process whilst Barajas et al. (2013) use entire cluster of countries.

The second banking sector structure determinant is the bank's interest rate margin. The bank efficiency measure is found to have an inverse relationship with the bank liabilities-to-GDP ratio. The findings are in line with the theory as in a well-developed and competitive market, profit margins - and in this case, net interest margins - are lower. Demirgüç-Kunt and Huizinga (1999) find that the higher the bank assets-to-GDP ratios, the lower the interest rate margins. In the banking sector development literature, no other study to the best of our knowledge reports the opposite where efficient banking sectors encourage banking sector depth, despite its theoretical plausibility. In competitive markets, banks faced with lower interest rate margins can maintain their rates of returns on equity by extending more credit which, in turn, increases their financial leverage and the size of the banking sector to GDP. The latter assumes that there is a demand for new credit in the economy and the increase in the supply will not reduce the net interest margins substantially.

The results also show that in countries in which the banking sector deepening contributes the most to long-term economic growth, the banking sector stability is found to be significant for the sector deepening. The lower the probability of banking sector insolvency the more developed the sector, according to model 24 . One possible explanation is that banks with higher credit ratings are in a better position to borrow at lower rates to fund their growth in assets than banks with lower credit ratings. In relation to the respective benchmarking literature, the findings are novel.

In relation to the macroeconomic factors that affect the development of the banking sector, the findings illustrate that inflation hinders the sector's development. The negative relationship between CPI and the bank assets-to-GDP ratio confirms the findings of Boyd et al. (1996, 2001), Chinn and Ito (2006), Djankov et al. (2007), and Barajas et al. (2013), that inflation deters the banking sector deepening. The sign of the CPI coefficient is as expected due to the negative effect of higher inflation rates on the real return on money and assets in general. The lower real rate of return under informational frictions in the credit markets reduces agents' incentive to lend and increases their incentive borrow (Boyd et al., 2001).

Moreover, on the basis of the estimates provided by model 24 it is sustained that the higher the household final consumption expenditure as a share of GDP, the lower the money supply to GDP ratio. More consumption levels are likely to reduce the money supply (M2) as bank deposits are withdrawn to facilitate payments to the goods and services' suppliers inside and outside the country. The finding is novel to the literature, as researchers examining the determinants of the banking sector development do not include measures of consumption in their studies. Similarly, the savings-to-GDP ratio is found to be negatively linked to the banking sector depth measure of money supply-to-GDP ratio. Since the savings-to-GDP ratio is calculated as the GNI less total consumption plus net transfers relative-to-GDP, the ratio can be viewed as the total size of investments-to-GDP ratio. As in the case of consumption, the larger the size of investment expenditure the more funds are required to be withdrawn from the banking sector. Beck et al. (2012)however, highlight the theoretical underpinnings of savings as a structural variable that determines the supply and demand for the financial services; empirical studies in the literature overlook the importance of this variable when investigating the banking sector development determinants and benchmarking the sector. 
In addition, the banking sector depth determinants models suggest that both governance and institutional factors are instrumental in affecting sectoral deepening. The first factor is political stability and the absence of violence. The findings of model 23 confirm previous results of Girma and Shortland (2004). For a banking sector to be able to promote economic activities and growth, a conducive political environment, in which regime stability and absence of violence prevail, is a precondition.

The second factor relating to governance and institutional is the rule of law. The results of model 22 illustrate the significance of the rule of law for banking sector deepening. This is in line with the findings of the established literature which explores the importance of investors' protection, law origins, and law enforcements for the development of the financial sector, led by the seminal work of La Porta et al. (1997, 1998). In particular, our findings demonstrate that the higher the extent to which agents have confidence in and abide by the rules of society-including the quality of contract enforcement, property rights, and courts - the more developed are the banking sectors in the 34 countries investigated. As far as regulatory quality is concerned, the estimates of model 21 suggest that in countries in which banking sector development contributes the most to long-term economic growth, the perception of the government ability to formulate and implement sound policies and regulations that permit and promote private sector development is positively associated with the sector depth. Apart from Huang (2010a)who includes the measure as an element of a governance index, no other study in the banking depth determinant and benchmarking literature employs the regulatory quality measure. The findings of this present study in relation to regulatory quality, political stability and absence of violence, and rule of law, lend support to those of Huang (2010a) which illustrates that good governance stimulates the banking sector development.

\section{Conclusions}

Studies in the literature concerned with the financial sector development benchmarking and the concept of the financial possibility frontier employ benchmarking models that assess the status of financial sector development in a country by using empirical models, the results of which are based on the means for countries within a given region/group or even broader for all the countries in the world (see Barajas, Beck, et al., 2013). This study instead identifies and uses the data for the countries in which the positive relationship between the banking sector and long-term economic growth is manifested at its highest possible level.

In addition, the benchmarking process implemented in this paper - which utilises different empirical models such as the mixed effects and the dynamic panel data models - can be applied in different disciplines where the researcher is concerned with identifying determinants of a certain phenomenon.

The paper's findings also extend the research of the banking sector depth determinants by exploring the banking sector structure, macroeconomics, and governance, institutional, and legal factors that are significant for the sector development in countries with the deepest banking-growth relationship. Although the factors are similar to those found to be significant in the broader literature, the findings of this study identify the ones that are more relevant for countries that aim to develop their banking sectors to spur long-term economic growth.

In the context of the finance-growth literature and the current debate on the exact relationship between the banking sector depth and long-term economic growth this paper introduces a novel benchmarking method that assesses the level of banking sector depth in a country against its counterparts in the top quartile countries. As a result, the method not only enables policymakers determine the status of their banking sector development (i.e. whether it is under- or overdeveloped) but also informs them about the factors that are required to be considered to optimise the positive effect of the sector on economic growth. In this sense the findings presented in this study are of significant importance as they establish a framework of analysis in terms of the nature as well as the stage of banking sector development to which policy makers can respond appropriately by implementing the right regulatory policies in order to harness the benefits of a developed banking sector and through this boost economic growth. In addition, the emerging evidence lends support to those who sustain that good governance can have beneficial effects to banking sector development which in turn will galvanize economic activity.

Further investigation as to why certain banking sector determinant factors are crucial for the sector development in countries where banking sector deepening is effective in stimulating income growth in income is warranted in the future. The financial possibility frontier concept and the benchmarking of the banking sectors with the aim of identifying the optimal level of development still remains novel. 


\section{References}

Aghion, P., and P. Howitt. 2009, The Economics of Growth. Cambridge, MA: MIT Press.

Acemoglu, D., and Johnson, S. 2005,Unbundling Institutions,Journal of Political Economy, vol. 113, no.5, pp. 949 995.

Ahmed, A. D. 2016,'Integration of Financial Markets, Financial Development and Growth: Is Africa Different?',Journal of International Financial Markets, Institutions and Money, vol. 42, pp. 43-59. doi:10.1016/j.intfin.2016.01.003

Al-Moulani, A., andAlexiou, C. 2017,Banking Sector Depth And Economic Growth Nexus: A Comparative Study Between The Natural Resource-Based And The Rest Of The World's Economies, International Review of Applied Economics, vol. 13, no.5, pp. 625-650.

Al-Hussainy, E., Coppola, A., Feyen, E., Ize, A., Kibuuka, K., and Ren, H. 2011, 2011: A Ready-to-Use Tool to Benchmark Financial Sectors Across Countries and Over Time. Washington DC.

Alexiou, C., Vogiazas, S. and Nellis, J. (2018) Reassessing the Relationship Between the Financial Sector and Economic Growth: Dynamic Panel Evidence, International Journal of Finance and Economics, vol. 23, no.2, pp. $155-173$.

Almarzoqi, R. M., Ben Naceur, S., and Kotak, A. 2015,What Matters for Financial Development and Stability? IMF Working Paper, WP/15/173(173), 1-43.

Ang, J. 2008. A Survey of Recent Developments in the Literature of Finance and Growth. Journal of Economic Surveys, vol.22 no. 3, pp. 1-43.

Arcand, J.-L., Berkes, E., and Panizza, U. 2012,Too much finance?IMF Working Papers. IMF Working Paper, No. 12/161, Washington DC: IMF.

Arellano, M., and Bond, S. 1991,Some Tests Of Specification For Panel Data: Monte Carlo Evidence And An Application To Employment Equations, The Review of Economic Studies, vol. 58, no. 2, pp. 277-297.

Asano, H. 1999, Financial Deregulation and Stability of Money Demand: The Australian Case, Australian Economic Papers, vol. 38, no. 4, pp.407-421.

Ayadi, R., Arbak, E., Ben Naceur, S., and Groen, W. P. De. 2013, Determinants of Financial Development across the Mediterranean. MEDPRO Technical Report, (29).

Bagehot, W. 1873, Lombard Street: A Description of the Money Market. New York: Dutton and Company.

Bahadir, B., and Valev, N. 2015,'Financial Development Convergence,Journal of Banking and Finance, vol.56, pp. 6171. doi:10.1016/j.jbankfin.2015.03.001

Baltagi, B. H. 2005,Econometric analysis of panel data. West Sussex, England: John Wiley \& Sons Ltd.

Baltagi, B. H., Demetriades, P. O., and Law, S. H. 2009,Financial Development And Openness: Evidence From Panel Data,Journal of Development Economics, vol.89, no. 2, pp. 285-296.

Barajas, A., Beck, T., Dabla-Norris, E., and Yousefi, S. 2013,Too Cold, Too Hot, or Just Right? Assessing Financial Sector Development Across the Globe, IMF Working Paper, WP/13/81, Washington DC.

Barajas, A., Chami, R., and Yousefi, R. 2013,The Finance and Growth Nexus Re-Examined: Do All Countries Benefit Equally? IMF Working Paper, No. 13/130, IMF, Washington DC.

Barth, J. R., Caprio, G., and Levine, R. 2004,Bank Regulation And Supervision: What Works Best?,Journal of Financial Intermediation, vol. 13, no. 2, pp. 205-248.

Bates, D. M., and Pinheiro, J. C. 1998, Computational Methods for Multilevel Modelling. Technical Memorandum, Bell Labs, Lucent Technologies, Murray Hill, NJ.

Beck, Dabla-Norris, E., and Barajas, A. 2012, Financial Possibility Frontier. In Enhancing Financial Sector Surveillance in Low-Income Countries - Background Paper (pp. 41-50). Washington DC: IMF.

Beck, T. 2014,Finance And Growth: Too Much Of A Good Thing?,Revue D'économie Du Développement, vol.22, pp. 67-72.

Beck, T., and De la Torre, A. 2006, The Basic Analytics Of Access To Financial Services, World Bank Policy Research Working Paper, (4026).

Beck, T., Demirgüç-Kunt, A., and Levine, R. 2003, Law, Endowments, and Finance,Journal of Financial Economics, vol.70, no.2, pp. 137-181.

Beck, T., and Feyen, E. 2013,Benchmarking Financial Systems: Introducing the Financial Possibility Frontier (No. 6615). Washington DC.

Beck, T., Feyen, E. H. B., Ize, A., and Moizeszowicz, F. 2008,Benchmarking Financial Development (No. 4638), Policy Research Working Paper Series, Washington DC. 
Beck, T., and Levine, R. 2003,Legal Institutions and Financial Development (No. 3136). World Bank Policy Research Working Paper. Washington DC.

Beck, T., Levine, R., and Loayza, N. 2000,Finance and the Sources of Growth,Journal of Financial Economics, vol. 58, pp. 261-300.

Ben Naceur, S., Cherif, M., and Kandil, M. 2014, What Drives Financial Sector Development in the MENA Region?,Borsa Istanbul Review, vol. 14, no.4, pp. 212-223. doi:http://dx.doi.org/10.2139/ssrn.1554512

Bencivenga, V., and Smith, B. 1992,Deficits, Inflation, And The Banking System In Developing Countries: The Optimal Degree Of Financial Repression,Oxford Economic Papers, vol. 44, no.4, pp.767-790.

Bhattacharyya, S., and Hodler, R. 2010,Do Natural Resource Revenues Hinder Financial Development? The Role of Political Institutions. OxCarre Working Papers. Centre for the Study of African Economies, Working Paper, No. 2010-40, University of Oxford, UK.

Bhattacharyya, S., and Hodler, R. 2014, Do Natural Resource Revenues Hinder Financial Development? The Role of Political Institutions, World Development, 57, 101-113.

Blundell, R., and Bond, S. 1998,Initial Conditions And Moment Restrictions In Dynamic Panel Data Models,Journal of Econometrics, vol. 87, no. 1, pp.115-143.

Blundell, R., Bond, S., and Windmeijer, F. 2001,Estimation In Dynamic Panel Data Models: Improving On The Performance Of The Standard GMM Estimator,Advances in Econometrics, vol.15, pp. 53-91.

Boyd, J. H., Levine, R., and Smith, B. D. 1996,Inflation and Financial Market Performance. Working Paper, No. 573D, Federal Reserve Bank of Minneapolis.

Boyd, J. H., Levine, R., and Smith, B. D. 2001.The Impact Of Inflation On Financial Sector Performance,Journal of Monetary Economics, vol. 47, pp. 221-248.

Chen, W., Hamori, S., and Kinkyo, T. 2016,Financial Development And Financial Openness Nexus: The Precondition Of Banking Competition,Applied Economics, vol. 48, no. 12, pp. 1130-1139. doi:10.1080/00036846.2015.1093087

Cherif, M., and Dreger, C. 2016,Institutional Determinants of Financial Development in MENA Countries, Review of Development Economics, vol. 20, no. 3, pp. 670-680.

Chinn, M. D., and Ito, H. 2006, What Matters For Financial Development? Capital Controls, Institutions, And Interactions,Journal of Development Economics, vol. 81, no. 1, pp. 163-192.

Čihák, M., Demirgüç-Kunt, A., Feyen, E., and Levine, R. 2012,Benchmarking Financial Systems around the World (No. WPS6175). World Bank Policy Research Working Paper. Washington DC.

David, A. C., Mlachila, M., and Moheeput, A. 2015,Does International Integration Matter For Financial Development In Africa?,Applied Economics, vol. 47, no.15, pp. 1525-1549. doi:10.1080/00036846.2014.997925

De la Torre, A., Feyen, E., and Ize, A. 2011,Financial Development: Structure and Dynamics. Policy Research Working Paper, No. 5854, Washington DC: World Bank.

Demetriades, P. O., and Andrianova, S. 2005, Sources and Effectiveness of Financial Development What We Know and What We Need to Know. United Nations University, 76.

Demirgüç-Kunt, A., and Huizinga, H. 1999,Determinants Of Commercial Bank Interest Margins And Profitability: Some International Evidence, The World Bank Economic Review, vol. 13, no. 2, pp. 379-408.

Djankov, S., McLiesh, C., and Shleifer, A. 2007,'Private Credit in 129 Countries', Journal of Financial Economics, vol. 84, no. 2, pp. 299-329.

Donia, L. 2012,Determinants of Banking Sector Development in Emerging Economies: Panel Estimation. Master of Arts' Thesis. The American University in Cairo.

Elsherif, M. A. 2015, The Determinants of Financial Development: Empirical Evidence from Egypt,The Macrotheme Review, vol. 3, no. 4, pp. 69-87.

Frees, E. W. 2004,Longitudinal and Panel Data: Analysis and Applications in the Social Sciences. Cambridge University Press.

Gazdar, K., and Cherif, M. 2014,The Quality Of Institutions And Financial Development In Mena Countries: An Empirical Investigation, Risk Governance \& Control, vol. 4, no. 4, pp. 65-80.

Girma, S., and Shortland, A. 2004,The Political Economy Of Financial Development (No. 04/21). Department of Economics Working Paper. Leicester, UK.

Goldsmith, R.1969,Financial Structure And Development. New Haven, CT: Yale University Press.

Graff, M., and Karmann, A. 2006, What Determines the Finance-growth Nexus? Empirical Evidence for Threshold Models,Journal of Economics, vol. 87. no.2, pp. 127-157.

Hamilton, L. 2012, Statistics with Stata: Version 12, Eighth Edition. Cengage Learning.

Herger, N., Hodler, R., and Lobsiger, M. 2008, What Determines Financial Development? Culture, Institutions Or Trade, Review of World Economics, vol. 144, no. 3, pp. 558-587. 
Huang, Y. 2010a,Determinants of Financial Development. London: Palgrave Macmillan.

Huang, Y. 2010b,Political Institutions and Financial Development: An Empirical Study,World Development, vol. 38, no. 12, pp. 1667-1677.

Huang, Y., and Temple, J. 2005,Does External Trade Promote Financial Development? (No. 05/575),Discussion Paper, Bristol.

King, R. G., and Levine, R. 1993, Finance And Growth: Schumpeter Might Be Right,The Quarterly Journal of Economics, vol.108, pp. 777-795.

Kutan, A., Samargabdi, N. and Sohag, K. 2017, Does Institutional Quality Matter for Financial Developmentand Growth? Further Evidence From Mena Countries, Australian Economic Papers, vol. 56, no. 3, pp. 228-248.

La Porta, R., Lopez-de-Silanes, F., Shleifer, A., and Vishny, R. W. 1997,Legal Determinants of External Finance,The Journal of Finance, vol. 2, no. 3, pp. 1131-1150.

La Porta, R., Lopez-de-Silanes, F., Shleifer, A., and Vishny, R. W. 1998,Law and Finance,Journal of Political Economy, vol. 106, no.6, pp. 11131-55.

Le, T.-H., Kim, J., and Lee, M. 2015,Institutional Quality, Trade Openness, and Financial Sector Development in Asia: An Empirical Investigation,Emerging Markets Finance and Trade, vol. 52, no.2, pp. 1047-1059. doi:10.1080/1540496X.2015.1103138

Levine, R. 2005, Finance and growth: Theory and evidence. Handbook of Economic Growth.

Levine, R., Loayza, N., and Beck, T. 2000,Financial Intermediation And Growth : Causality And Causes,Journal of Monetary Economics, vol. 46, pp. 31-77.

Ndikumana, L. 2005, Financial Development, Financial Structure, And Domestic Investment: International Evidence,Journal of International Money and Finance, vol. 4, no. 24, pp. 651-673.

Rajan, R. G., and Zingales, L. 2003,The Great Reversals: The Politics Of Financial Development In The Twentieth Century,Journal of Financial Economics, vol. 69, no. 1, pp. 5-50.

Robinson, J. 1952, The Generalization of the General Theory. In The Rate of Interest and Essays, edited by J. Robinson, pp. 67-146. London: Macmillan.

Roodman, D. 2006,How To Do Xtabond2: An Introduction To "Difference" And "System" GMM In Stata, Working Paper, Center for Global Development, London.

Roodman, D. 2009a, How To Do Xtabond2: An Introduction To Difference And System GMM In Stata,The Stata Journal, vol. 1, no. 9, pp. 86-136.

Roodman, D. 2009b,Practitioners Corner: A Note On The Theme Of Too Many Instruments,Oxford Bulletin of Economics and Statistics, vol. 71, no. 1, pp. 135-158.

Roubini, N., and Sala-i-Martin, X. 1992,Financial Repression And Economic Growth,Journal of Development Economics, vol. 39, no. 1, pp. 5-30.

Schumpeter, J. A. 1911, A Theory of Economic Development. Cambridge: Harvard University Press.

Snijders, T. 2003, Multilevel Analysis. In M. S. Lewis-Beck, A. Bryman, and T. F. Liao (Eds.), The SAGE Encyclopedia of Social Science Research Methods (pp. 673-677). Sage Publications, Inc.

StataCorp. 2013,Stata 13 Base Reference Manual. College Station, TX: StataCorp LP.

Torres-Reyna, O. (2015) Multilevel analysis. Princeton University Library, Data and Statistical Services.

Vogiazas, S., Alexiou, C. and Orafiri, O. 2018, Drivers of The Real Effective Exchange Rates in High And UpperMiddle Income Countries, Australian Economic Papers, vol.58, no. 1, 41-53.

Windmeijer, F. 2005,A Finite Sample Correction For The Variance Of Linear Efficient Two-Step GMM Estimators,Journal of Econometrics, vol. 126, no. 1, pp. 25-51.

Wu, L. 2010,Mixed Effects Models for Complex Data. Boca Raton, Florida: Chapman \& Hall/CRC.

Xu, Z. 2000,Financial Development, Investment, And Economic Growth, Economic Inquiry, vol. 38, no. 2, pp. 331344. 


\section{DATA APPENDIX}

\begin{tabular}{|c|c|}
\hline Variable Name & Source \\
\hline \multicolumn{2}{|c|}{$\begin{array}{l}\text { List of the Economic Growth Ratios \& Proxies Employed as Dependent Variables in the Mixed Effects } \\
\text { Models and as Independent Variables in the System GMM for Dynamic Panel Data Models: }\end{array}$} \\
\hline GDP per capita (constant 2005 US\$) & World Development Indicators, World Bank \\
\hline GDP per capita growth (annual \%) & World Development Indicators, World Bank \\
\hline GNI per capita (constant 2005 US\$) & World Development Indicators, World Bank \\
\hline GNI per capita growth (annual \%) & World Development Indicators, World Bank \\
\hline Gross capital formation (\% of GDP) & World Development Indicators, World Bank \\
\hline $\begin{array}{l}\text { Gross fixed capital formation, private } \\
\text { sector (\% of GDP }\end{array}$ & World Development Indicators, World Bank \\
\hline \multicolumn{2}{|c|}{$\begin{array}{l}\text { List of the Banking Sector Depth Ratios Employed as Independent Variables in the Mixed Effects Models } \\
\text { and as Dependent Variables in the System GMM for Dynamic Panel Data Models: }\end{array}$} \\
\hline $\begin{array}{l}\text { Domestic credit to private sector by banks } \\
(\% \text { of GDP }\end{array}$ & World Development Indicators, World Bank \\
\hline $\begin{array}{l}\text { Assets of Deposit Banks (US\$ mn) to } \\
\text { Total GDP in Current Prices (US\$ mn) }\end{array}$ & Passport Database - Euromonitor International \\
\hline $\begin{array}{l}\text { Liabilities of Deposit Banks (US\$ mn) to } \\
\text { Total GDP in Current Prices (US\$ mn }\end{array}$ & Passport Database - Euromonitor International \\
\hline $\begin{array}{l}\text { Money and quasi money (M2) as \% of } \\
\text { GDP }\end{array}$ & World Development Indicators, World Bank \\
\hline Liquid liabilities (M3) as \% of GDP & World Development Indicators, World Bank \\
\hline \multicolumn{2}{|c|}{ List of the Controlling Variables Employed in the Mixed Effects Models } \\
\hline $\begin{array}{l}\text { Foreign direct investment, net inflows (\% } \\
\text { of GDP) }\end{array}$ & World Development Indicators, World Bank \\
\hline $\begin{array}{l}\text { General government final consumption } \\
\text { expenditure }(\% \text { of GDP) }\end{array}$ & World Development Indicators, World Bank \\
\hline Inflation, consumer prices (annual \%) & World Development Indicators, World Bank \\
\hline School enrollment, secondary (\% gross) & World Development Indicators, World Bank \\
\hline Trade (\% of GDP) & World Development Indicators, World Bank \\
\hline \multicolumn{2}{|c|}{$\begin{array}{l}\text { List of the Independent Variables Employed in the System GMM for Dynamic Panel Data Models: Banking } \\
\text { Stability, Efficiency \& Competition Measures }\end{array}$} \\
\hline Bank Z-score & World Development Indicators, World Bank \\
\hline Bank credit to bank deposits (\%GDP) & World Development Indicators, World Bank \\
\hline Bank net interest margin (\%) & World Development Indicators, World Bank \\
\hline Bank cost to income ratio (\%) & World Development Indicators, World Bank \\
\hline Bank concentration (\%) & World Development Indicators, World Bank \\
\hline 5-bank asset concentration & World Development Indicators, World Bank \\
\hline \multicolumn{2}{|c|}{$\begin{array}{l}\text { List of the Independent Variables Employed in the System GMM for Dynamic Panel Data Models: } \\
\text { Macroeconomics \& Demography Variables }\end{array}$} \\
\hline Manufacturing, value added (\% of GDP ) & World Development Indicators, World Bank \\
\hline Industry value added (\% of GDP) & World Development Indicators, World Bank \\
\hline Services etc. value added (\% of GDP) & World Development Indicators, World Bank \\
\hline
\end{tabular}




\begin{tabular}{|c|c|}
\hline Gross saving (\% of GDP) & World Development Indicators, World Bank \\
\hline Household final consumption (\% of GDP) & World Development Indicators, World Bank \\
\hline Consumer Price Index (2000-100) & World Development Indicators, World Bank \\
\hline Population Total & World Development Indicators, World Bank \\
\hline $\begin{array}{l}\text { List of the Independent Variables Employed in } \\
\text { Governance, Institutional \& Legal Indicators }\end{array}$ & System GMM for Dynamic Panel Data Models: \\
\hline Voice and accountability & Worldwide Governance Indicators, World Bank \\
\hline Political stability and absence of violence & Worldwide Governance Indicators, World Bank \\
\hline Rule of law & Worldwide Governance Indicators, World Bank \\
\hline Control of corruption & Worldwide Governance Indicators, World Bank \\
\hline Government effectiveness & Worldwide Governance Indicators, World Bank \\
\hline Regulatory quality & Worldwide Governance Indicators, World Bank \\
\hline Legal origins: British & $\begin{array}{l}\text { Global Development Network Growth, World } \\
\text { Bank }\end{array}$ \\
\hline
\end{tabular}

Table A1: Countries with banking sectors that contribute the most to economic growth

$\begin{array}{llllll}1 \text { Japan } & 3 \text { Switzerland } & 5 \text { Israel } & 7 \text { Armenia } & 7 \text { Hong Kong SAR, China } \\ 2 \text { Austria } & 4 \text { Cameroon } & 5 \text { Malaysia } & 7 \text { Belarus } & 7 \text { Italy } \\ 2 \text { Korea, Rep. } & 4 \text { Russian Federation } & 5 \text { United States } & 7 \text { Botswana } & 7 \text { Kuwait } \\ 3 \text { France } & 5 \text { Belgium } & 6 \text { Azerbaijan } & 7 \text { Congo, Dem. Rep. } & 7 \text { Malta } \\ 3 \text { Latvia } & 5 \text { Brunei Darussalam } & 6 \text { Bahamas, The } & 7 \text { Congo, Rep. } & 7 \text { Panama } \\ 3 \text { Mauritius } & 5 \text { China } & 6 \text { India } & 7 \text { Egypt, Arab Rep. } & 7 \text { Trinidad and Tobago } \\ 3 \text { Sri Lanka } & 5 \text { Germany } & 6 \text { Mexico } & 7 \text { Equatorial Guinea } & \end{array}$

